\title{
Comprehensive Gene Expression Profiling in the Prefrontal Cortex Links Immune Activation and Neutrophil Infiltration to Antinociception
}

\author{
Kay-Wee Poh, ${ }^{1}$ Jin-Fei Yeo, ${ }^{1}$ Christian S. Stohler, ${ }^{4}$ and Wei-Yi Ong ${ }^{2,3}$ \\ Departments of ${ }^{1}$ Oral and Maxillofacial Surgery and ${ }^{2}$ Anatomy and ${ }^{3}$ Neurobiology and Ageing Research Programme, National University of Singapore, \\ Singapore 119260, Singapore, and ${ }^{4}$ School of Dentistry, University of Maryland, Baltimore, Maryland 21201
}

Functional neuroimaging studies have implicated the prefrontal cortex (PFCTX) in descending modulation of pain and the placebo effect. This study was performed to elucidate comprehensive PFCTX gene expression in an animal model of persistent trigeminal pain. Adult male $\mathrm{C} 57 \mathrm{BL} / 6 \mathrm{~J}$ mice received facial carrageenan injection and showed sustained increase in nociceptive responses. Microarray analyses of differentially expressed genes in the PFCTX at $3 \mathrm{~d}$ after injection showed "immune system process" as the dominant ontology term and increased mRNA expression of S100a8, S100a9, Lcn2, Il2rg, Fcgr1, Fcgr2b, C1qb, Ptprc, Ccl12, and Cd52 were verified by RT-PCR. Upregulation of S100A8, S100A9, and lipocalin 2 (LCN2) were confirmed by Western blots, and cells in the PFCTX were double immunolabeled with MPO, indicating they were neutrophils. Analyses of blood of facial carrageenan-injected mice also showed increased mRNA expression of these markers, suggesting transmigration of activated neutrophils into the brain. Other immune-related genes, Il2rg, Fcgr $2 b$, C1qb, Ptprc, and Ccl12 were upregulated in the PFCTX but not blood. Approximately $70 \%$ of S100A9-positive cells in the PFCTX of carrageenan-injected mice were located in capillaries adherent to endothelial cells, whereas $30 \%$ were within the brain parenchyma. Carrageenan-injected mice showed significantly reduced nociceptive responses after injection of C terminus of murine S100A9 protein in the lateral ventricles and PFCTX but not somatosensory barrel cortex. Together, these findings demonstrate activation of immunerelated genes in the PFCTX during inflammatory pain and highlight an exciting role of neutrophils in linking peripheral inflammation with immune activation of the PFCTX and antinociception.

\section{Introduction}

Recent studies have indicated an important role of the prefrontal cortex (PFCTX) during pain. Activation of the PFCTX is consistently found in acute and chronic pain and models of experimental pain (Ingvar, 1999; Peyron et al., 2000; Maihöfner et al., 2004; Maihöfner and Handwerker, 2005). Frontal lobe activity is associated with cognitive and attention processing during noxious stimulation (Baron et al., 1999; Maihöfner and Handwerker, 2005), and increased activity of the PFCTX is associated with increased pain thresholds in experimental animals (Zhang et al., 1997). Functional neuroimaging of the PFCTX shows increased activity during expectation of analgesia after administration of placebo, implying its involvement in the cognitive control of pain (Petrovic et al., 2002; Benedetti et al., 2005; Wager, 2005; Ramos, 2007). Using functional molecular positron emission tomography imaging, placebo-induced activation of endogenous opioid neurotransmission is detected in a number of brain regions, including the rostral anterior cingulate, orbitofrontal and dorsolat-

\footnotetext{
Received May 13, 2011; revised Sept. 9, 2011; accepted 0ct. 11, 2011.

Author contributions: W.-Y.O. designed research; K.-W.P. and W.-Y.O. performed research; K.-W.P., J.-F.Y., C.S.S., and W.-Y.O. analyzed data; K.-W.P., J.-F.Y., C.S.S., and W.-Y.O. wrote the paper.

This work was supported by the Academic Research Fund from the National University of Singapore.

Correspondence should be addressed to Dr. Wei-Yi Ong, Department of Anatomy, National University of Singapore, Singapore 119260, Singapore. E-mail: wei_yi_ong@nuhs.edu.sg.

DOI:10.1523/JNEUROSCI.2389-11.2012

Copyright $\odot 2012$ the authors $\quad 0270-6474 / 12 / 320035-11 \$ 15.00 / 0$
}

eral PFCTXs, insula, nucleus accumbens, amygdala, thalamus, hypothalamus, and periaqueductal gray (Zubieta and Stohler, 2009). Neuroimaging and connectivity analyses indicate that increased activity of prefrontal and cingulate cortices decrease pain perception via the descending pain inhibitory system (Valet et al., 2004; Xie et al., 2009). This involves the periaqueductal gray (Mayer and Price, 1976; Brooks and Tracey, 2005), which when stimulated, produces behavioral analgesia in rats, cats, monkeys, and humans (Basbaum and Fields, 1984; Cui et al., 1999) through descending influences that decrease the sensitivity of dorsal horn neurons to afferent noxious stimuli (Liebeskind et al., 1973).

The more recent literature recognizes an important role of the immune system and glial cells in development of pain hypersensitivity (DeLeo et al., 2004; Scholz and Woolf, 2007; Ren and Dubner, 2008). Immune cells, glia, and neurons also form an integrated network in which activation of an immune response modulates the excitability of pain pathways (Ren and Dubner, 2010). Immune and immune-related cells, keratinocytes and vascular endothelial cells secrete anti-inflammatory cytokines, proresolution lipid mediators, and opioid peptides to suppress pain (Rittner et al., 2008; Hua and Cabot, 2010; Ren and Dubner, 2010). In addition, microglia and astrocytes are immunocompetent cells that respond like immune cells within the CNS (Watkins and Maier, 1999). Activated microglia release mediators that act on neurons and sensitize nociceptors (Verge et al., 2004; Coull et al., 2005; Zhuang et al., 2007). Astrocytes are intimately associated with neurons and are 
in a unique position to regulate synaptic activity (Ren and Dubner, 2010).

Despite the importance of the PFCTX in pain and analgesia, little is known about the associated changes in gene expression induced by pain. The present study was performed to elucidate comprehensive gene expression assessment and to determine the functional significance of the gene expression changes with respect to its effect on pain.

\section{Materials and Methods}

Animals and chronic inflammatory pain

Mice and facial carrageenan injection. Adult male C57BL/6J mice, 6-8 weeks of age and weighing $\sim 20-30 \mathrm{~g}$, were purchased from the Laboratory Animals Centre, Singapore. Treated mice received three facial injections of $50 \mu \mathrm{l}$ carrageenan each $(2 \mathrm{mg} / 50 \mu \mathrm{l}$ saline of lambda carrageenan; Sigma) each in the subcutaneous tissue over the right/left ophthalmic, maxillary, and mandibular regions using a $1 \mathrm{ml}$ sterile syringe with a 27 gauge $\times 1 / 2$ inch needle while still under anesthesia $(75 \mathrm{mg} / \mathrm{kg}$ ketamine plus $1 \mathrm{mg} / \mathrm{kg}$ medetomidine). Carrageenan injection produced a constant swelling of $\sim 4$ $\mathrm{mm}$ in diameter and causes allodynia in the injected area in the days after the injection (Ng and Ong, 2001). Control mice were anesthetized but did not receive facial carrageenan injection. All procedures involving animals were in accordance with guidelines and regulations of the Committee for Research and Ethical Issues of International Association for the Study of Pain and approved by the Institutional Animal Care and Use Committee of National University of Singapore.

Assessment of mechanical allodynia. Mice were labeled with a coded number tag on their tails, to allow the behavioral responses of an individual mouse to be followed at different time intervals. Behavioral assessments were performed in a blinded manner as described previously (Vos et al., 1994). Mice were tested individually in a deep rectangular stainless steel tank, sized $60 \times 40 \times 25 \mathrm{~cm}$ (length $\times$ width $\times$ height). The experimenter reached into the tank with a von Frey hair to habituate the mice to the reaching movements for 5-10 min before testing. Mice were observed during this time to ensure that they were able to move freely. Test stimuli were administered when the mice were neither moving nor freezing and with all four paws placed on the ground while exhibiting sniffing behavior. Subsequent stimuli were applied only when the mouse resumed this position after the preceding stimulation. The carrageenaninjected maxillary area of the face was probed 20 times with a von Frey hair (Touch-Test Sensory Evaluator; North Coast Medical). A filament delivering $1.4 \mathrm{~g}$ of force $(4.17 \log$ units $=13.73 \mathrm{mN})$ was used. The number of immediate asymmetric face grooming/scratching strokes was summed to compute the total number of face strokes exhibited by an animal after 20 stimulations. The mean and SD of the total responses were then calculated for each experimental group, and possible significant differences between the means were elucidated using one-way ANOVA with Bonferroni's multiple comparison post hoc test. $p<0.05$ was considered significant.

\section{Microarray analyses}

Sixteen mice were used in this portion of the study. Eight mice were uninjected controls. The remainder were injected with carrageenan on the left or right side of the face. Behavioral assessment was performed by von Frey hair stimulation of the injected maxillary area of the face or the corresponding uninjected controls (four mice in each group). The carrageenan-injected mice were killed after $3 \mathrm{~d}$, at the estimated time of peak nociceptive responses. Sixteen independent samples for microarray analyses were used with no pooling of samples, four for the right PFCTX of mice receiving left-sided facial carrageenan injection, four for the right PFCTX of untreated controls, and similarly for the left PFCTX of mice receiving right-sided facial carrageenan injection and its corresponding controls. Mice were deeply anesthetized with intraperitoneal injection of $75 \mathrm{mg} / \mathrm{kg}$ ketamine plus $1 \mathrm{mg} / \mathrm{kg}$ medetomidine and decapitated. Brains were harvested, and the left and right PFCTXs were dissected out and stored at $-80^{\circ} \mathrm{C}$ freezer until analysis. The dissected region of the PFCTX is the dorsolateral portion of the frontal cortex, $0-1 \mathrm{~mm}$ from the frontal pole according to a mouse brain atlas of Paxinos and Franklin (2004).
Gene expression profiles of the tissues were established using Affymetrix Mouse Genome 4302.0 microarrays. Total RNA was isolated using TRIzol reagent (Invitrogen) according to the protocol of the manufacturer, and RNeasy Mini kit (Qiagen) was used to purify the RNA. The RNA was then submitted to the Biosensor Focus Interest Group Core Facility Lab at National University of Singapore, where RNA quality was determined using the Agilent 2100 Bioanalyzer, and cRNA was generated and labeled by the one-cycle target labeling method. The acceptance criteria for RNA quality were $260 / 280$ ratio $\geq 1.80$ and RNA integrity number $\geq 8.0$. cRNA generated from each sample was hybridized to a single array according to standard Affymetrix protocols. Initial image analysis of the microarray chips was performed using the Affymetrix GCOS 1.2 software. Data were exported to GeneSpring version 7.3 (Agilent Technologies) software for additional analysis using parametric tests based on the cross gene error model. Unpaired $t$ tests were used to identify differentially expressed genes between experimental and control animals. Differentially expressed genes were classified based on their known biological functions using the DAVID (Database for Annotation, Visualization, and Integrated Discovery) software (Dennis et al., 2003; Huang da et al., 2009).

\section{Validation of microarray results}

Real time RT-PCR. The same RNA extracted for the microarray analysis was used for the validation of the microarray results. Samples were reverse transcribed using High-Capacity cDNA Reverse Transcription kits (Applied Biosystems). Reaction conditions were $25^{\circ} \mathrm{C}$ for $10 \mathrm{~min}, 37^{\circ} \mathrm{C}$ for $120 \mathrm{~min}$, and $85^{\circ} \mathrm{C}$ for $5 \mathrm{~min}$. Real-time RT-PCR amplification was performed in the 7500 Real-time PCR system using TaqMan Universal PCR Master Mix and gene-specific primers and probes according to the protocols of the manufacturer (Applied Biosystems). $\beta$-Actin was used as an internal control. All primers and probes were synthesized by Applied Biosystems. The PCR conditions were an initial incubation of $50^{\circ} \mathrm{C}$ for 2 min and $95^{\circ} \mathrm{C}$ for $10 \mathrm{~min}$, followed by 40 cycles of $95^{\circ} \mathrm{C}$ for $15 \mathrm{~s}$ and $60^{\circ} \mathrm{C}$ for $1 \mathrm{~min}$. All reactions were performed in triplicate. The threshold cycle (CT), which correlates inversely with the levels of target mRNA, was measured as the number of cycles at which the reporter fluorescence emission exceeds the preset threshold level. The amplified transcripts were quantified using the comparative CT method (Livak and Schmittgen, 2001) with the formula for relative fold change $=2^{-\Delta \Delta \mathrm{CT}}$. The mean and SD were calculated, and possible significant differences were analyzed using Student's $t$ test. $p<0.05$ was considered significant.

Western blot analyses. Eight mice were used for this portion of the study. Four mice were injected with carrageenan on the left side of the face and killed $3 \mathrm{~d}$ after injection. The remaining four were used as untreated controls. They were deeply anesthetized and decapitated, and the right PFCTX was removed and homogenized in $10 \mathrm{vol}$ of ice-cold lysis buffer ( $150 \mathrm{~mm}$ sodium chloride, $50 \mathrm{~mm}$ Tris hydrochloride, 0.25 mM EDTA, $1 \%$ Triton X-100, $0.1 \%$ sodium orthovanadate, and $0.1 \%$ protease inhibitor cocktail, $\mathrm{pH}$ 7.4). After centrifugation at $10,000 \times g$ for $10 \mathrm{~min}$ at $4^{\circ} \mathrm{C}$, the supernatant was collected. The protein concentrations in the preparation were then measured using the Bio-Rad protein assay kit. Before resolving the sample, the proteins were denatured by heating the sample in the presence of SDS and a reducing agent (DTT) for $10 \mathrm{~min}$ at $95-100^{\circ} \mathrm{C}$. Protein standards containing molecular weight of 250,150 , $100,75,50,37,25,20,15$, and $10 \mathrm{kDa}$ were used (Precision Plus Protein Dual Color Standards; Bio-Rad). The homogenates $(50 \mu \mathrm{g})$ were resolved in 10\% SDS-polyacrylamide gels under reducing conditions and electrotransferred to a polyvinylidene difluoride (PVDF) membrane. Nonspecific binding sites on the PVDF membrane were blocked by incubating with $5 \%$ nonfat milk in $0.1 \%$ Tween 20/TBS (TTBS) for $1 \mathrm{~h}$. The PVDF membrane was then incubated overnight in goat polyclonal antibodies to S100A8 (diluted 1:50; Santa Cruz Biotechnology), S100A9 (diluted 1:50; Santa Cruz Biotechnology), or lipocalin 2 (LCN2) (diluted 1:200; R \& D Systems), in 1\% bovine serum albumin in TTBS. After washing with TTBS, the membrane was incubated with horseradish peroxidase-conjugated anti-goat $\operatorname{IgG}$ (1:1000 in TTBS; Pierce) for $1 \mathrm{~h}$ at room temperature. Negative controls were performed using protein samples of facial carrageenan-injected mice incubated with only secondary antibodies. Immunoreactivity was visualized using a chemiluminescence substrate 
(Supersignal West Pico; Pierce). Loading controls were performed by incubating the blots at room temperature for $10 \mathrm{~min}$ with stripping buffer (Restore Western Blot Stripping Buffer; Pierce), followed by reprobing with a mouse monoclonal antibody to $\beta$-actin (diluted 1:10,000 in TTBS; Sigma) and horseradish peroxidase-conjugated anti-mouse IgG (1:10,000 in TTBS; Pierce). Exposed films containing blots were scanned, and the densities of the bands were measured using Gel-Pro Analyzer 3.1 program (Media Cybernetics). The densities of the S100A8, S100A9, and LCN2 bands were normalized against that of $\beta$-actin, and the mean ratios were calculated. Possible significant differences between the values from the carrageenan-injected and control mice were then analyzed using Student's $t$ test. $p<0.05$ was considered significant.

Immunohistochemistry. Four 3-d post-carrageenan-injected mice and four untreated control mice were used for this portion of the study. The brains were fresh harvested without perfusion and immersed in $4 \%$ paraformaldehyde overnight. The brains were trimmed until the first sign of the PFCTX was observed (3.20 mm rostral to bregma) according to a mouse brain atlas (Paxinos and Franklin, 2004). Forty to 50 sections of 12 $\mu \mathrm{m}$ each were then collected, and one in six sections were selected for immunohistochemistry. The sections were subjected to antigen retrieval by heating at $95-99^{\circ} \mathrm{C}$ in Dako target retrieval solution for $20 \mathrm{~min}$, followed by three washes in PBS. They were then incubated in a blocking solution composed of 5\% donkey serum (Vector Laboratories) and $0.1 \%$ Triton X-100 for $1 \mathrm{~h}$, followed by goat polyclonal antibodies to S100A8 (diluted 1:100 in PBS; Santa Cruz Biotechnology), S100A9 (diluted 1:100 in PBS; Santa Cruz Biotechnology), or LCN2 (diluted 1:100 in PBS; Santa Cruz Biotechnology), rabbit polyclonal antibody to myeloperoxidase (MPO; diluted 1:100 in PBS; Abcam), or rabbit polyclonal antibody to von Willebrand factor (vWF; diluted 1:500 in PBS; Santa Cruz Biotechnology) overnight. The sections were then washed three times in PBS and incubated for $1 \mathrm{~h}$ at room temperature in 1:200 dilutions of Alexa Fluor 488 anti-goat IgG and Alexa Fluor 555 anti-rabbit IgG (Invitrogen). Finally, sections were mounted and examined using a Carl Zeiss LSM 510 confocal microscope. The mean and SD of number of labeled cells per unit area were calculated, and possible significant differences were analyzed using Student's $t$ test. $p<0.05$ was considered significant.

\section{Comparison of perfused versus non-perfused brain and findings from blood}

Twenty-three days post-carrageenan-injected mice and four untreated controls were used for this portion of the study, to compare perfused versus non-perfused brain tissue. The blood was harvested by aspiration through the heart and collected in RNAprotect Animal Blood Tubes (Qiagen) for RT-PCR analyses before harvesting the brain. Of the 24 animals, four were untreated controls and perfused with $0.9 \%$ saline until the venous return was clear, and tissues were used for RT-PCR; four were injected with carrageenan and perfused, and tissues were used for RT-PCR; four were injected with carrageenan and non-perfused, and tissues were used for RT-PCR; four were injected with carrageenan and perfused, and tissues were used for immunohistochemistry; and four were injected with carrageenan and non-perfused, and tissues were used for immunohistochemistry. Real-time RT-PCR and immunohistochemistry were performed as in the validation study described above. The mean and SD of the number of S100A9-expressing cells in blood vessels or brain parenchyma/unit area were calculated, and possible significant differences were analyzed using Student's $t$ test. $p<0.05$ was considered significant.

\section{Functional analyses}

Synthesis of S100A9 peptide. A peptide identical to the C terminus of murine S100A9 protein (mS100A9p) (H-E-K-L-H-E-N-N-P-R-G-H-GH-S-H-G-K-G) was synthesized by GenScript based on a previously published sequence (Raftery et al., 1996). This peptide was synthesized in solid phase by the fluorenylmethyloxycarbonyl technique. The characterization and purification of the peptide was performed by HPLC, and its mass was evaluated by ESI-MS. The peptide were diluted in saline at a final concentration of $2 \mathrm{mg} / \mathrm{ml}$.

Intracerebroventricular mS100A9p injection. A total of 40 mice divided into five groups of eight mice each were used in this portion of the work. Two groups received left facial carrageenan injection and bilateral intra-
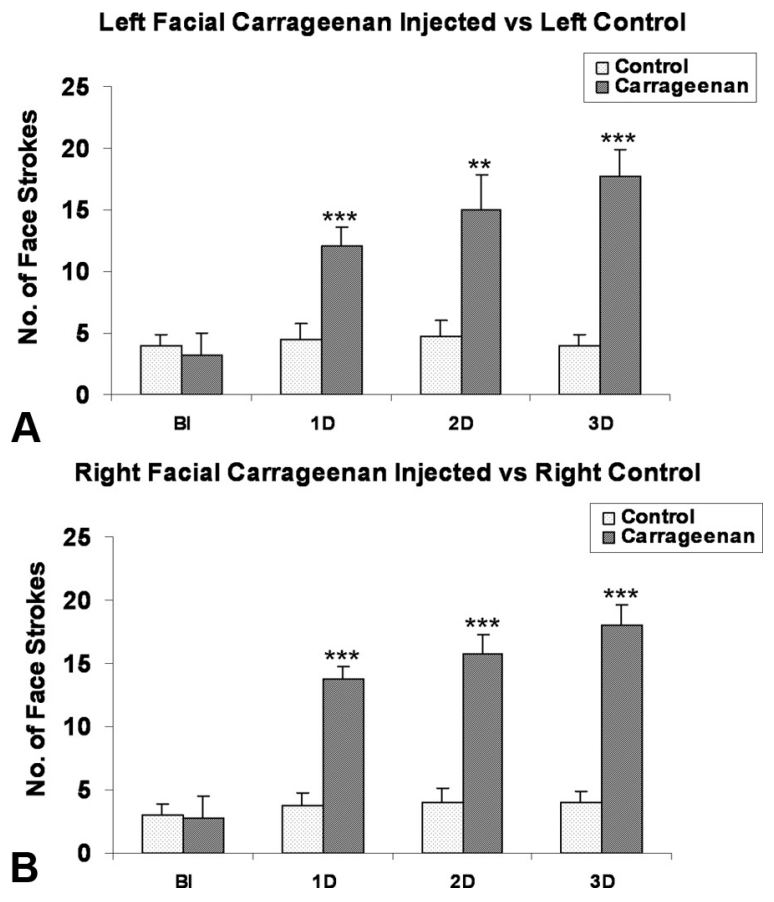

Figure 1. Responses to von Frey hair stimulation of the face after facial carrageenan injection. $\boldsymbol{A}$, Left-sided facial carrageenan injection. $\boldsymbol{B}$, Right-sided facial carrageenan injection. The $y$-axis represents number of responses to von Frey hair stimulation of the carrageenan-injected areas of the face. BI, Before injection; 1D, 2D, 3D, 1, 2, and 3 d after facial carrageenan injection; Control, untreated control; Carrageenan, facial carrageenan injection. Analyzed by Student's $t$ test. ${ }^{* *} p<0.01 ;{ }^{* * *} p<0.001$.

cerebroventricular injection of 2 or $0.25 \mu \mathrm{g} / \mu \mathrm{lmS100A9p}$ (GeneScript) in a volume of $1 \mu \mathrm{l}$ in each ventricle on the third day after facial carrageenan injection (coordinates: $0.7 \mathrm{~mm}$ caudal to bregma, $1.0 \mathrm{~mm}$ lateral to the midline, $2.0 \mathrm{~mm}$ from the surface of the cerebral cortex) (Yeo et al., 2004). The dose of mS100A9p was determined based on a pilot study using a small number of animals. Another group (eight mice) received left facial carrageenan injection and bilateral intracerebroventricular injection of saline (vehicle control) on the third day after facial carrageenan injection. The remaining two groups (eight mice per group) were controls without facial carrageenan injection that received bilateral intracerebroventricular injection of $2 \mu \mathrm{g} / \mu \mathrm{lmS100A9p}$ or $1 \mu \mathrm{l}$ of saline in each ventricle on the third day. Responses to von Frey hair stimulation were quantified daily in a blinded manner as described above.

PFCTX mS100A9p injection. A total of 40 mice divided into five groups of eight mice each were used in this portion of the work. Two groups received left facial carrageenan injection and bilateral intracortical injection of 2 or $0.5 \mu \mathrm{g} / \mu \mathrm{l} \mathrm{mS100A9p}$ in a volume of $0.5 \mu \mathrm{l}$ each into both left and right dorsolateral PFCTX on the third day after facial carrageenan injection (coordinates: $2.5 \mathrm{~mm}$ rostral to bregma, $1.5 \mathrm{~mm}$ lateral to the midline, $1.5 \mathrm{~mm}$ from the surface of the cerebral cortex) (Paxinos and Franklin, 2004). The doses were determined based on a pilot study using a small number of animals. Another group (eight mice) received left facial carrageenan injection and bilateral intracortical injection of saline (vehicle control) on the third day after facial carrageenan injection.

The remaining two groups (eight mice per group) were control groups (without facial carrageenan injection) that received bilateral intracortical injection of $2 \mu \mathrm{g} / \mu \mathrm{lmS100A9p}$ or saline, in a volume of $0.5 \mu \mathrm{l}$ each into both left and right dorsolateral PFCTX on the third day. Responses to von Frey hair stimulation were quantified daily in a blinded manner. Mean and SD of the total responses were then calculated for each experimental group, and possible significant differences between the means were examined using one-way ANOVA with Bonferroni's multiple comparison post hoc test. $p<0.05$ was considered significant.

Somatosensory cortex mS100A9p injection. An additional two groups of eight mice each were used to study the effect of mS100A9p in the somato- 
Table 1. Differentially upregulated genes in the PFCTX after facial carrageenan injection

\begin{tabular}{|c|c|c|c|c|c|}
\hline Gene & Gene symbol & $\begin{array}{l}\text { Fold change in right } \\
\text { frontal cortex } \\
\text { (mean } \pm S D \text { ) }\end{array}$ & $p$ value & $\begin{array}{l}\text { Fold change in left } \\
\text { frontal cortex } \\
\text { (mean } \pm S D \text { ) }\end{array}$ & $p$ value \\
\hline S100 calcium binding protein A8 (calgranulin A) & $5100 a 8$ & $20.7 \pm 5.6$ & 0.000038 & $7.5 \pm 4.6$ & 0.0022 \\
\hline Lipocalin 2 & Len2 & $16.1 \pm 0.9$ & 0.018 & $10.4 \pm 8.1$ & 0.0023 \\
\hline S100 calcium binding protein A9 (calgranulin B) & $5100 a 9$ & $15.0 \pm 5.3$ & 0.00017 & $9.1 \pm 5.4$ & 0.0046 \\
\hline Interferon, $\alpha$-inducible protein 27 & Ifi27 & $3.9 \pm 0.7$ & 0.00050 & $3.0 \pm 0.9$ & 0.0019 \\
\hline von Willebrand factor homolog & $v W F$ & $3.7 \pm 1.2$ & 0.004 & $2.3 \pm 0.3$ & 0.00078 \\
\hline Secretoglobin, family $3 \mathrm{~A}$, member 1 & Scgb3a1 & $2.8 \pm 1.0$ & 0.0041 & $2.4 \pm 1.4$ & 0.047 \\
\hline Lysozyme & Lyzs & $2.7 \pm 0.8$ & 0.0023 & $2.2 \pm 0.3$ & 0.00033 \\
\hline Interferon-induced transmembrane protein 3 & Ifitm3 & $2.4 \pm 0.3$ & 0.001 & $2.3 \pm 0.1$ & 0.00019 \\
\hline Trophoblast-specific protein $\beta$ & $T p b p b$ & $2.4 \pm 0.5$ & 0.0034 & $1.6 \pm 0.2$ & 0.00044 \\
\hline Transglutaminase 2, C polypeptide & $\operatorname{Tgm} 2$ & $2.4 \pm 0.1$ & 0.0098 & $2.2 \pm 0.5$ & 0.0015 \\
\hline Intercellular adhesion molecule & Icam1 & $2.3 \pm 0.6$ & 0.010 & $1.7 \pm 0.5$ & 0.029 \\
\hline Junction adhesion molecule 2 & Jam2 & $2.3 \pm 0.3$ & 0.00050 & $2.8 \pm 0.9$ & 0.0026 \\
\hline Peptidylprolyl isomerase C-associated protein & Ppicap & $2.2 \pm 0.3$ & 0.025 & $1.9 \pm 0.5$ & 0.0076 \\
\hline Breast carcinoma amplified sequence 2 & Bcas2 & $2.2 \pm 0.5$ & 0.029 & $1.6 \pm 0.2$ & 0.0023 \\
\hline Chemokine (C-C motif) ligand 12 & $\mathrm{Cd} 12$ & $2.2 \pm 1.0$ & 0.047 & $1.8 \pm 0.5$ & 0.012 \\
\hline Ceruloplasmin & $C p$ & $2.1 \pm 0.2$ & 0.024 & $1.9 \pm 0.5$ & 0.013 \\
\hline Nel-like 2 homolog (chicken) & Nell2 & $2.1 \pm 0.5$ & 0.0089 & $5.0 \pm 0.4$ & 0.0000011 \\
\hline $\begin{array}{l}\text { Tyrosine 3-monooxygenase/tryptophan 5-monooxygenase activation } \\
\text { protein, } \zeta \text { polypeptide }\end{array}$ & Ywhaz & $2.1 \pm 0.3$ & 0.00069 & $1.8 \pm 0.3$ & 0.0022 \\
\hline Histocompatibility 2, Q region locus 7 & H2-Q7 & $2.1 \pm 1.0$ & 0.043 & $2.1 \pm 0.3$ & 0.00065 \\
\hline Fc receptor, IgG, low affinity Ilb & Fcgr2b & $2.1 \pm 0.3$ & 0.0025 & $1.9 \pm 0.3$ & 0.0012 \\
\hline Protein tyrosine phosphatase, receptor type, C & Ptprc & $2.0 \pm 0.3$ & 0.0073 & $2.0 \pm 0.1$ & 0.0057 \\
\hline Oncostatin M receptor & Osmr & $2.0 \pm 0.4$ & 0.0023 & $1.7 \pm 0.6$ & 0.033 \\
\hline Interferon-induced transmembrane protein 1 & Ifitm1 & $2.0 \pm 0.2$ & 0.0045 & $1.7 \pm 0.1$ & 0.00047 \\
\hline Interleukin 2 receptor, gamma chain & $112 \mathrm{rg}$ & $1.9 \pm 0.1$ & 0.00019 & $1.7 \pm 0.4$ & 0.017 \\
\hline Receptor transporter protein 4 & Rtp4 & $1.9 \pm 0.4$ & 0.0032 & $1.8 \pm 0.4$ & 0.012 \\
\hline Placenta-specific 8 & Plac8 & $1.9 \pm 0.7$ & 0.039 & $1.7 \pm 0.3$ & 0.0048 \\
\hline C-type lectin domain family 14 , member a & Clec14a & $1.8 \pm 0.4$ & 0.0095 & $1.9 \pm 0.3$ & 0.013 \\
\hline Lymphocyte antigen 6 complex, locus A & Ly6a & $1.8 \pm 0.1$ & 0.00049 & $1.6 \pm 0.2$ & 0.0019 \\
\hline Complement component 1, q subcomponent, $\beta$ polypeptide & $C 1 q b$ & $1.8 \pm 0.1$ & 0.016 & $1.5 \pm 0.2$ & 0.0054 \\
\hline C-type lectin domain family 4, member a3 & Clec4a3 & $1.8 \pm 0.4$ & 0.026 & $1.7 \pm 0.5$ & 0.025 \\
\hline Integrin $\alpha 4$ & ltga4 & $1.7 \pm 0.3$ & 0.0036 & $1.9 \pm 0.4$ & 0.0055 \\
\hline Fc receptor, IgG, high affinity I & Fcgr1 & $1.7 \pm 0.4$ & 0.0091 & $1.6 \pm 0.3$ & 0.010 \\
\hline Claudin 5 & Cldn5 & $1.7 \pm 0.2$ & 0.00056 & $1.8 \pm 0.2$ & 0.00028 \\
\hline Suppressor of cytokine signaling 3 & Socs3 & $1.7 \pm 0.4$ & 0.018 & $1.6 \pm 0.2$ & 0.0034 \\
\hline Vimentin & Vim & $1.6 \pm 0.04$ & 0.0093 & $1.5 \pm 0.1$ & 0.0018 \\
\hline Friend leukemia integration 1 & Fli1 & $1.6 \pm 0.2$ & 0.0019 & $1.6 \pm 0.2$ & 0.041 \\
\hline Immunoglobulin superfamily, member 7 & lgsf7 & $1.6 \pm 0.2$ & 0.0020 & $1.5 \pm 0.2$ & 0.0010 \\
\hline Zinc finger, ZZ domain containing 3 & Zzz3 & $1.6 \pm 0.5$ & 0.036 & $1.5 \pm 0.2$ & 0.0078 \\
\hline CD52 antigen & $C d 52$ & $1.6 \pm 0.04$ & 0.00067 & $1.6 \pm 0.5$ & 0.036 \\
\hline Immediate early response 3 & ler3 & $1.6 \pm 0.3$ & 0.0093 & $1.6 \pm 0.2$ & 0.0084 \\
\hline Family with sequence similarity 13 , member $C$ & Fam13c & $1.6 \pm 0.2$ & 0.0063 & $1.6 \pm 0.1$ & 0.000068 \\
\hline Glucocorticoid-induced leucine zipper & Gilz & $-1.5 \pm 0.1$ & 0.0071 & $-1.6 \pm 0.1$ & 0.027 \\
\hline Zinc finger protein 339 & Zfp339 & $-1.6 \pm 0.1$ & 0.022 & $-1.8 \pm 0.1$ & 0.0016 \\
\hline Basic transcription element binding protein 1 & Bteb1 & $-1.6 \pm 0.1$ & 0.032 & $-1.6 \pm 0.1$ & 0.025 \\
\hline TATA box binding protein (Tbp)-associated factor, RNA polymerase I, C & Taf1c & $-1.6 \pm 0.1$ & 0.025 & $-1.7 \pm 0.2$ & 0.039 \\
\hline Polymerase (RNA) III (DNA directed) polypeptide C & Polr3c & $-1.7 \pm 0.1$ & 0.0046 & $-1.5 \pm 0.04$ & 0.00014 \\
\hline Arrestin domain containing 2 & Arrdc2 & $-1.7 \pm 0.2$ & 0.028 & $-2.2 \pm 0.1$ & 0.016 \\
\hline Serum/glucocorticoid regulated kinase & Sgk & $-1.8 \pm 0.1$ & 0.0034 & $-1.9 \pm 0.1$ & 0.0072 \\
\hline
\end{tabular}

Show is upregulation or downregulation by $\geq 1.5$-fold compared with untreated control mice after contralateral right- or left-sided facial carrageenan injection. Bold indicate genes validated by real-time RT-PCR.

sensory (barrel) cortex. The same dose as the PFCTX injections was used. The two groups received left facial carrageenan injection and bilateral intracortical injection of either $2 \mu \mathrm{g} / \mu \mathrm{lmS100A9p}$ or saline in a volume of $0.5 \mu \mathrm{l}$ into both left and right somatosensory cortex on the third day after facial carrageenan injection (coordinates: $1.5 \mathrm{~mm}$ caudal to bregma, $3 \mathrm{~mm}$ lateral to the midline, $1.5 \mathrm{~mm}$ from the surface of the cerebral cortex) (Paxinos and Franklin, 2004). Responses to von Frey hair stimulation were quantified daily in a blinded manner as described above.

\section{Results}

Animal model of chronic inflammatory pain

Facial carrageenan-injected mice showed increasing response behaviors to stimulation with the von Frey filament up to the third day after carrageenan injection. Statistically significant increases in responses compared with control mice were established at post-injection days 1, 2, and 3 (Fig. 1). The mice were killed on the third day after injection, corresponding to the estimated time of peak nociceptive responses, based on previous studies and were used for microarray and real-time RT-PCR validation.

\section{Microarray analyses}

The gene expression profiles in the right PFCTX of mice that received left facial carrageenan injection were compared with the corresponding data of untreated controls, and differentially expressed genes with $p$ value of $<0.05$ were further analyzed. Of 

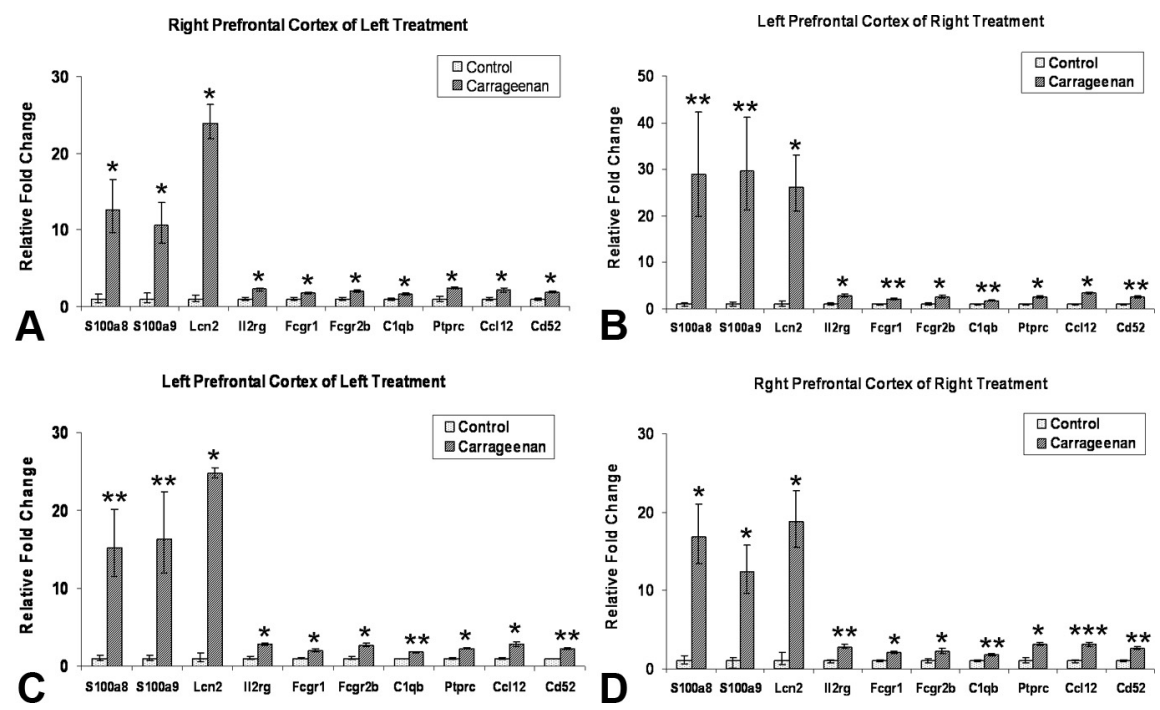

Figure 2. Real-time RT-PCR analyses of immune-related genes in (non-perfused) PFCTX of facial carrageenan-injected mice compared with untreated controls. A, Right PFCTX of left facial carrageenan-injected mice. $\boldsymbol{B}$, Left PFCTX of right facial carrageenan-injected mice. $\boldsymbol{C}$, Left PFCTX of left facial carrageenan-injected mice. $\boldsymbol{D}$, Right PFCTX of right facial carrageenaninjected mice. Analyzed by Student's $t$ test. ${ }^{*} p<0.05$; ${ }^{* *} p<0.01$; ${ }^{* * *} p<0.001$.

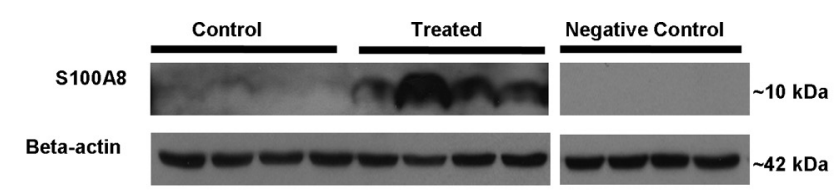

A
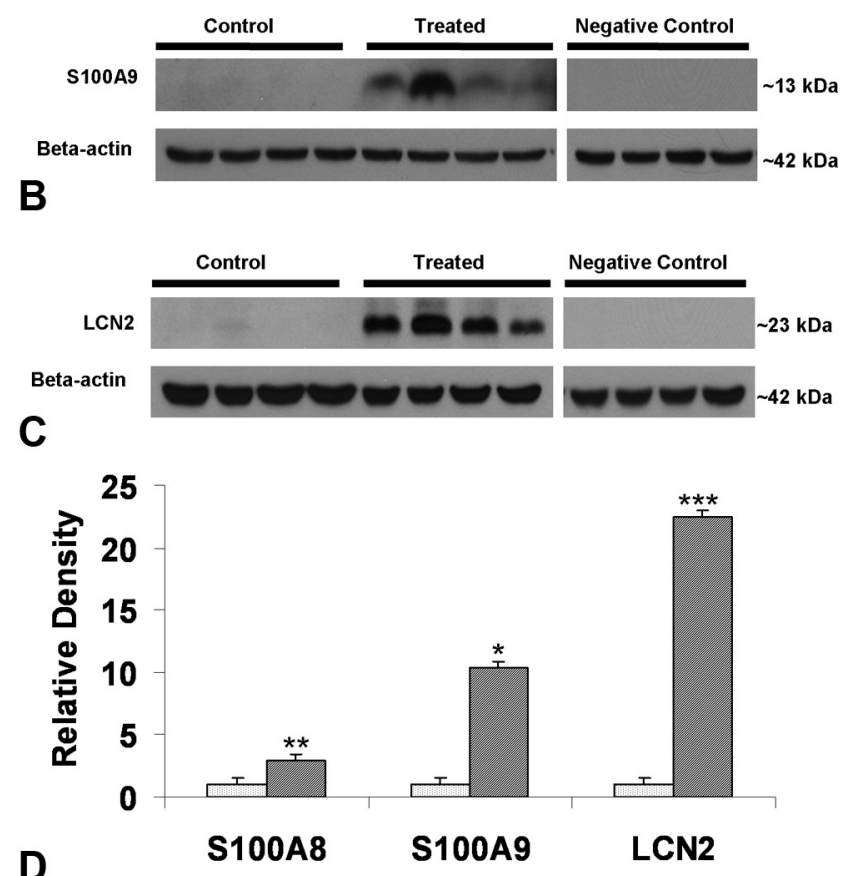

Figure 3. Western blot analyses of S100A8, S100A9, and LCN2 in PFCTX homogenates of untreated and $3 \mathrm{~d}$ facial post-carrageenan-injected mice. $\boldsymbol{A}$, The antibody to $\mathrm{S} 100 \mathrm{~A} 8 \mathrm{detected} \mathrm{a}$ single band at $\sim 10 \mathrm{kDa}$ in homogenates from facial carrageenan-injected mice but not untreated controls. $\boldsymbol{B}$, The antibody to $\$ 100 \mathrm{~A} 9$ detected a single band at $\sim 13 \mathrm{kDa}$ in homogenates from carrageenan-injected mice. $\boldsymbol{C}$, The antibody to LCN2 detected a single band at $\sim 23 \mathrm{kDa}$ in homogenates from carrageenan-injected mice. No bands were detected in negative controls. $\boldsymbol{D}$, Quantitation of densitometry readings. Significant increase in the density of detected bands was observed in carrageenan-injected mice compared with untreated controls. Analyzed by Student's $t$ test. ${ }^{*} p<0.05 ;{ }^{* *} p<0.01$; ${ }^{* * *} p<0.001$. these, 194 genes had fold change $\geq 1.5$. Similarly, gene expression profiles of the left prefrontal cortices in mice that received right facial carrageenan injection were compared with data from untreated controls, and differentially expressed genes with $p<0.05$ were further analyzed. Of these, 467 genes were altered at a fold change of $\geq 1.5$.

Genes that were common to the 467 and 194 genes in the PFCTX after either left- or right-sided facial carrageenan injection were further identified. This step was taken to increase the yield for greater pain-related specificity, minimizing the impact of false positives and to disregard possible side-specific changes in the function of the PFCTXs. The result was a list of 76 genes, of which genes with uncertain ontology were ignored, leaving 48 known genes that had $\geq 1.5$-fold change (Table $1)$. They were classified using the Gene Ontology (GO) term enrichment analysis from the DAVID resource website (http:// david.abcc.ncifcrf.gov/) (Dennis et al., 2003; Huang da et al., 2009). It was found that the categories with the lowest Fisher's exact $p$ value (12 of the 48 genes) were annotated with the GO term "immune system process" (Fisher's exact $p$ value $=2.4 \mathrm{E}-6$ ). All 12 genes in this category, together with $\$ 100 a 8$ and Lcn2, were selected for additional validation in this study.

Changes in gene expression that were unique to either the left or right PFCTX were also analyzed. Three hundred ninety-one and 118 genes were exclusively altered in the left and right PFCTXs, respectively. These included 161 and 54 known genes that had $\geq 1.5$-fold change in the left or right PFCTXs, respectively. Genes that were differentially expressed only in the left PFCTX were annotated with GO terms such as "response to DNA damage stimulus," "DNA repair," and "cellular response to stress"; those that are differentially expressed only in the right PFCTX were annotated with GO terms such as "response to stimulus," "immune system process," and "response to external stimulus" (data not shown).

\section{Validation of microarray results}

Real time RT-PCR

Real-time RT-PCR was used to validate the results of the microarray analyses for the genes identified above. Ten of 14 genes could be validated in the PFCTX contralateral to the side of the facial carrageenan injection, namely S100a8, S100a9, Lcn2, Il2rg, Fcgr1, Fcgr2b, C1qb, Ptprc, Ccl12, and Cd52. The relative fold changes of S100a8, S100a9, Lcn2, Il2rg, Fcgr1, Fcgr2b, Clqb, Ptprc, Ccl12, and Cd52 for the right PFCTX after left facial carrageenan injection were 12.6, 10.6, 24.0, 2.3, 1.7, 2.1, 1.6, 2.5, 2.1, and 1.9, respectively (Fig. 2A), whereas the relative fold changes of S100a8, S100a9, Lcn2, Il2rg, Fcgr1, Fcgr2b, Clqb, Ptprc, Ccl12, and Cd52 for the left PFCTX after right facial carrageenan injection were 29.0, 29.6, 26.3, 2.8, 2.1, 2.7, 1.8, 2.5, 3.4, and 2.6, respectively (Fig. 2B).

Real-time RT-PCR analyses of the PFCTXs ipsilateral to the facial carrageenan injection showed similar increases in gene expression compared with data established for the contralateral PFCTXs. The relative fold changes of S100a8, S100a9, Lcn2, Il2rg, Fcgr1, Fcgr2b, Clqb, Ptprc, Ccl12, and Cd52 for the left PFCTX after left facial carrageenan injection were 15.2, 16.4, 24.8, 2.8, 2.0, 2.7, 1.8, 2.3, 2.8, and 2.3, respectively (Fig. 2C), whereas the 

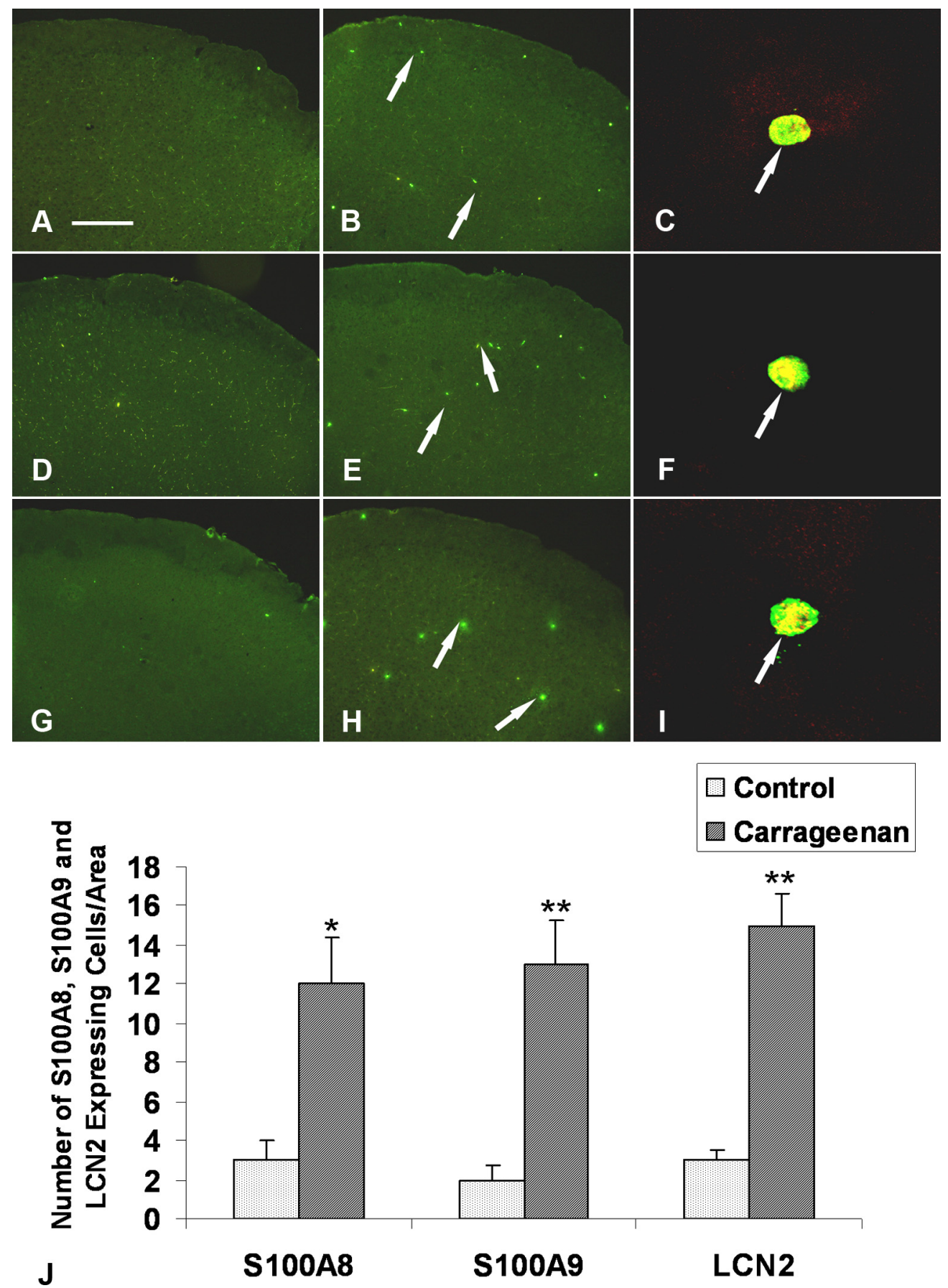

Figure 4. Immunohistochemical labeling of S100A8, S100A9, or LCN2 in the PFCTX. A-C, S100A8 immunolabeled sections of the PFCTX. Low level of S100A8 labeling is present in the cortex of untreated controls $(\boldsymbol{A})$, but an increased number of stained cells is present in the PFCTX of facial carrageenan-injected mice ( $\boldsymbol{B}$, arrows). $\boldsymbol{C}$, Higher-magnification micrograph from a facial carrageenan-injected mouse showed colocalization of S100A8 with MPO, a neutrophil marker (red-green overlay, arrow). D-F, S100A9 immunolabeled sections of the PFCTX. Low level of $\$ 100 \mathrm{~A} 9$ labeling is present in the cortex of untreated controls $(\boldsymbol{D})$, but an increased number of stained cells is present in the PFCTX of facial carrageenan-injected mice (E, arrows). $\boldsymbol{F}$, Higher-magnification micrograph from a facial carrageenan-injected mouse showed colocalization of S100A9 with MPO (red-green overlay, arrow). G-I, LCN2 immunolabeled sections of the PFCTX. Low level of LCN2 labeling is present in the cortex of untreated controls ( $G$ ), but an increased number of stained cells is present in the PFCTX of facial carrageenan-injected mice $(\boldsymbol{H}$, arrows). $\boldsymbol{I}$, Higher-magnification micrograph from a facial carrageenan-injected mouse showed colocalization of LCN2 with MPO (red-green overlay, arrow). J, Significantly increased number of S100A8-, S100A9-, and LCN2-expressing cells are detected in the PFCTX of carrageenan-injected mice compared with untreated controls. Analyzed by Student's $t$ test. ${ }^{*} p<0.05 ;{ }^{* *} p<0.01$. The areas examined were $2 \times 1.6 \mathrm{~mm}\left(3.2 \mathrm{~mm}^{2}\right)$, and the arrows in the figures indicate some of the immunopositive cells. Scale bar: $\boldsymbol{A}, \boldsymbol{B}, \boldsymbol{D}, \boldsymbol{E}, \mathbf{G}, \boldsymbol{H}, 400 \mu \mathrm{m} ; \boldsymbol{C}, \boldsymbol{F}, \boldsymbol{I}, 10 \mu \mathrm{m}$.

relative fold changes of S100a8, S100a9, Lcn2, Il2rg, Fcgr1, Fcgr2b, $C 1 q b$, Ptprc, Ccl12, and Cd52 for the right PFCTX after right facial carrageenan injection were 16.8, 12.4, 18.8, 2.8, 2.0, 2.2, 1.8, 3.2, 3.1 , and 2.6, respectively (Fig. $2 D$ ).
Western blot analyses

Antibodies to S100A8, S100A9, and LCN2 detected bands at 10, 13 , and $23 \mathrm{kDa}$, respectively, in PFCTX homogenates, consistent with the expected molecular weights of these proteins (Grim- 
Effect of Perfusion on mRNA Expression in the Prefrontal Cortex
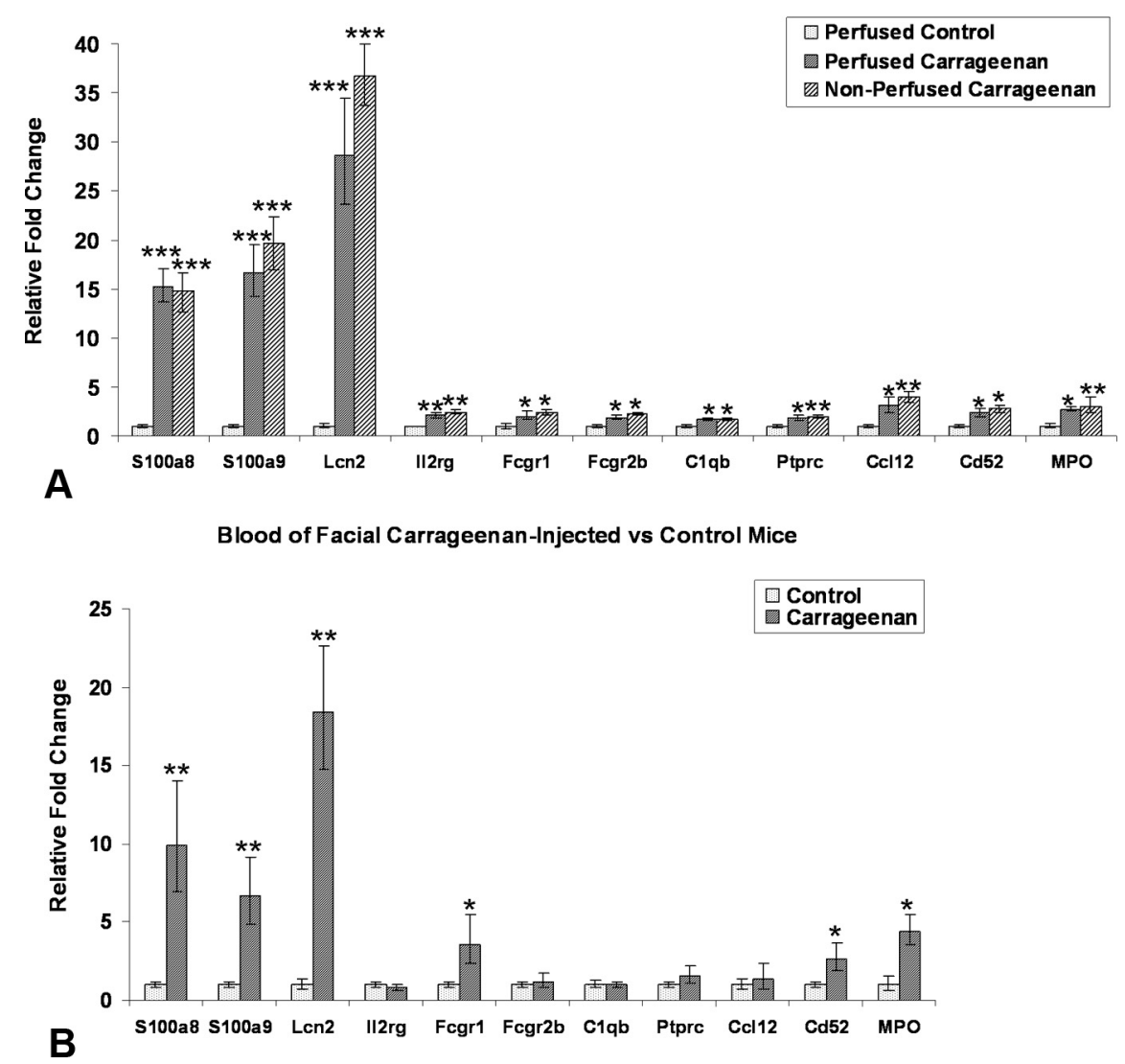

Figure 5. Comparison of non-perfused versus perfused PFCTX and results from blood. $A$, Effects of perfusion on mRNA expression of immune-related genes in the PFCTX after facial carrageenan injection compared with untreated perfused controls. $\boldsymbol{B}$, Analyses of blood of facial carrageenan-injected versus untreated control mice. Analyzed by one-way ANOVA with Bonferroni's multiple comparison post hoc test. Asterisks indicate significant difference compared with controls: ${ }^{*} p<0.05$; ${ }^{* *} p<0.01$; ${ }^{* * *} p<0.001$.

baldeston et al., 2003; Yan et al., 2007; Johansson et al., 2008). No band was detected in the negative control experiment. The antibody to $\beta$-actin reacted against a band at $42 \mathrm{kDa}$. Significant increases in the density ratios of S100A8, S100A9, and LCN2 to $\beta$-actin with ratios of $2.9,10.3$, and 22.5 , respectively, were observed in the $3 \mathrm{~d}$ post-carrageenan-injected mice compared with matched control mice, indicating upregulation of S100A8, S100A9, and LCN2 (Fig. 3).

\section{Immunohistochemistry}

Immunofluorescence labeling for S100A8 protein showed very few immunopositive cells in the PFCTX of the control mice (Fig. $4 A$ ). In comparison, increased expression of S100A8 was detected in the PFCTX of mice, $3 \mathrm{~d}$ after facial carrageenan injection (Fig. 4 B). Double immunolabeling showed that S100A8 was colocalized with MPO, a neutrophil marker (Fig. 4C). Likewise, very few cells were immunolabeled for S100A9 in the PFCTX of the control mice (Fig. 4D), but an increased number of immunopositive cells was detected in the PFCTX of mice $3 \mathrm{~d}$ after facial carrageenan injection (Fig. $4 E$ ). The immunopositive cells were double labeled with MPO (Fig. $4 F$ ). LCN2 showed very few or no immunopositive cells in the PFCTX of the control mice (Fig. 4G), but upregulation was observed in the PFCTXs of carrageenaninjected mice (Fig. 4H). The LCN2-positive cells were double labeled with MPO (Fig. 4I). S100A8-, S100A9-, and LCN2labeled cells appear evenly distributed in the cortex, and only occasional cells are found at the junction of cortex and the pia mater. Quantitative analyses showed that S100A8, S100A9, and LCN2 were localized in $82 \pm 2.9,78 \pm$ 1.9 , and $86 \pm 1.5 \%$ of MPO-positive cells, respectively, indicating that they were localized in neutrophils (Fig. $4 J$ ).

\section{Comparison of perfused versus non-perfused brain and findings from blood \\ $R T$-PCR of brain}

Increased expression of S100a8, S100a9, Lcn2, Il2rg, Fcgr1, Fcgr2b, C1qb, Ptprc, Ccl12, Cd52, and Mpo were detected in the right PFCTXs of perfused mice after left facial carrageenan injection compared with perfused control mice. The relative fold changes were 15.3, 16.7, 28.6, 2.1, 2.1, $1.9,1.7,1.8,3.1,2.4$, and 2.8, respectively. No significant differences were observed between non-perfused PFCTXs and perfused PFCTXs (Fig. 5A).

\section{$R T-P C R$ of blood}

Significantly increased expression of S100a8, S100a9, Lcn2, Fcgr1, Cd52, and Mpo were detected in the blood of $3 \mathrm{~d}$ facial postcarrageenan-injected mice compared with control mice. The relative fold changes were $9.9,6.7,18.4,3.6,2.7$, and 4.4 , respectively. The remaining genes that were not significantly altered in the blood include Il2rg, Fcgr2b, C1qb, Ptprc, and Ccl12 (Fig. 5B).

\section{Immunohistochemical analyses of} non-perfused versus perfused PFCTX

The relation between S100A9-positive cells and brain capillaries was examined by double immunolabeling with an endothelial cell marker, vWF. The PFCTX of facial carrageenan-injected mice showed an increased number of S100A9-positive cells. The cells were localized in capillaries (71 \pm $4.2 \%)$ or the brain parenchyma $(29 \pm 4.2 \%)$ (Fig. $6 A)$.

As with non-perfused tissues, perfused PFCTX of facial carrageenan-injected mice showed an increased number of S100A9-positive cells. S100A9-expressing cells were localized in capillaries $(69 \pm 2.4 \%)$ or the brain parenchyma $(31 \pm 2.4 \%)$ (Fig. 6B). No significant difference in the number of S100A9expressing cells was found between perfused and non-perfused PFCTX (Fig. 6C).

\section{Functional analyses}

Intracerebroventricular injection of $m S 100 A 9 p$

Mice that received bilateral intracerebroventricular injection of 2 $\mu \mathrm{g}$ of mS100A9p in each lateral ventricle on the third day after facial carrageenan injection showed significantly reduced nociceptive responses $12 \mathrm{~h}$ after injection compared with facial carrageenan plus intracerebroventricular saline-injected mice (Fig. $7 A$ ). Carrageenan-injected mice that received bilateral intracerebroventricular injection of $0.25 \mu \mathrm{g}$ of mS100A9p in each ventricle showed no significant difference from controls that received facial carrageenan plus intracerebroventricular saline. Mice in- 
jected with mS100A9p and without facial carrageenan injection showed no difference in responses from baseline.

Intracortical injections of $m S 100 \mathrm{~A} 9 \mathrm{p}$ into the PFCTX or somatosensory cortices

Mice that received bilateral intracortical injection of $1 \mu \mathrm{g}$ of mS100A9p (per side) in the dorsolateral PFCTX on the third day after facial carrageenan injection showed significantly reduced nociceptive responses $12 \mathrm{~h}$ after injection compared with facial carrageenan plus intracortical saline-injected mice (Fig. $7 B$ ). In contrast, bilateral intracortical injection of $1 \mu \mathrm{g}$ of mS100A9p (per side) into the somatosensory cortex showed no significant difference compared with controls and absence of antinociception (Fig. 7C).

\section{Discussion}

The present study was performed to determine gene expression changes in the PFCTX during inflammatory pain. Analysis of microarray data of the PFCTX after facial carrageenan injection indicates "immune system process" as the dominant ontology term based on the lowest Fisher's exact $p$ value. Increased expression of S100a8, S100a9, Lcn2, Il2rg, Fcgr1, Fcgr2b, C1qb, Ptprc, Ccl12, and Cd52 were verified by real-time RT-PCR in the ipsilateral and contralateral PFCTXs after carrageenan injection to either side.

S100A8 and S100A9 are members of the S100 family of calcium binding proteins, which are highly expressed in neutrophils and monocytes (Gebhardt et al., 2006; Soyfoo et al., 2009). They are involved in cytokine gene regulation (Sunahori et al., 2006), arachidonic acid binding/shuttling (Kerkhoff et al., 1999, 2001), and regulation of endothelial cell integrity. S100A8/S100A9 induces loss of cell-cell contacts and increased permeability of endothelial monolayers, leading to increased leukocyte extravasation during inflammation (Newton and Hogg, 1998; Viemann et al., 2005, 2007). The finding of high levels of expression of S100A8 and S100A9 in the PFCTX after inflammatory pain induced by facial carrageenan injection is consistent with results of a previous study, which showed increased S100A8 and S100A9 transcripts in the frontal cortex after hindpaw inflammation (Mitchell et al., 2008). LCN2 is expressed in macrophages (Flo et al., 2004) and neutrophils (Bundgaard et al., 1994) and is an important component of the innate immune response (Flo et al., 2004). Interleukin 2 receptor, gamma chain (IL2RG) is a component of the receptors for IL-2, IL-4, IL-7, IL-9, and IL-15, is expressed on the surface of neutrophils and is critical for the development and function of lymphocytes (Habib et al., 2002; Ratthé et al., 2007). The highaffinity IgG receptor Fc $\gamma$ RI (CD64) is expressed on the surface of neutrophils and monocytes (Kakinoki et al., 2004) and smallsized neurons (Andoh and Kuraishi, 2004) and is implicated in pain (Handwerker et al., 1991). Fc $\gamma$ RIIb (CD32) is expressed on B lymphocytes (Blank et al., 2005) and regulates the function of these cells (Rahman et al., 2007). C1QB is one of the heterotrimers of $\mathrm{Clq}$ that is involved in the complement cascade of innate immune response (Sontheimer et al., 2005) and is expressed in neurons (Spielman et al., 2002). Protein-tyrosine phosphatase, receptor-type C (PTPRC) is expressed by leukocytes and plays a role in lymphocyte activation (Forsyth et al., 1993). Chemokine (C-C motif) ligand 12 (CCL12) is expressed in macrophages and is a potent monocyte chemotactic factor that signals through CCR2 (Sarafi et al., 1997). CD52 is a cell-surface glycoprotein expressed by $\mathrm{B}$ and $\mathrm{T}$ lymphocytes, natural killer cells, monocytes, and macrophages (Rodig et al., 2006). The above genes are involved in the regulation of inflammatory and immune processes.

Genes associated with interferon function were also altered in the PFCTX after facial carrageenan injection. These include interferon, $\alpha$-inducible protein 27 (Ifi27), interferon-induced transmembrane protein 1 (Ifitm1), and interferon-induced transmembrane protein 3 (Ifitm3). Ifi27 belongs to a family of small, interferon- $\alpha$-inducible genes and is upregulated in keratinocytes of psoriatic skin (Suomela et al., 2004). Ifitm 1 and Ifitm 3 belong to a family of interferon-induced transmembrane genes that encode cell-surface proteins that modulate cell adhesion and influence cell differentiation (Tanaka et al., 2005). Interferon may induce upregulation of immune-related genes in the PFCTX after facial carrageenan injection.

Genes encoding adhesion molecules were increased in the PFCTX after facial carrageenan injection. These include $\alpha 4$ integrins (Itga4), intercellular adhesion molecule (Icam1), junction adhesion molecule 2 (Jam2), and claudin 5 (Cldn5). $\alpha 4$-Integrins are important adhesion molecules involved in the 
Effect of mS100A9p on Behavioral Responses - Lateral Ventricle

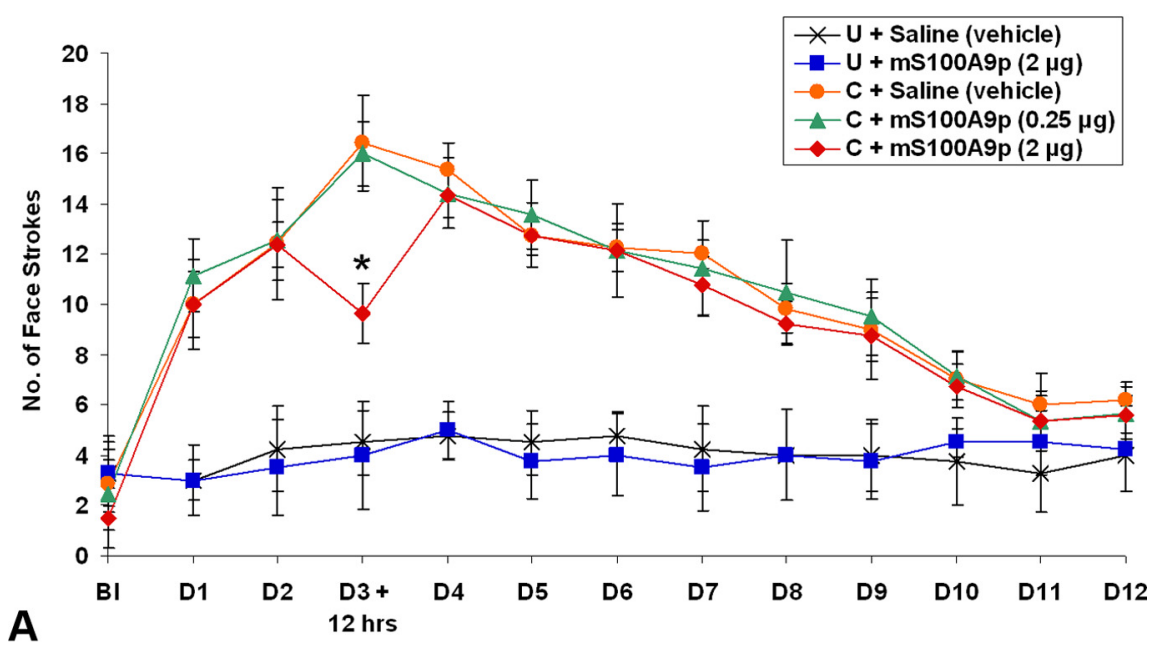

Effect of mS100A9p on Behavioral Responses - Dorsolateral Prefrontal Cortex

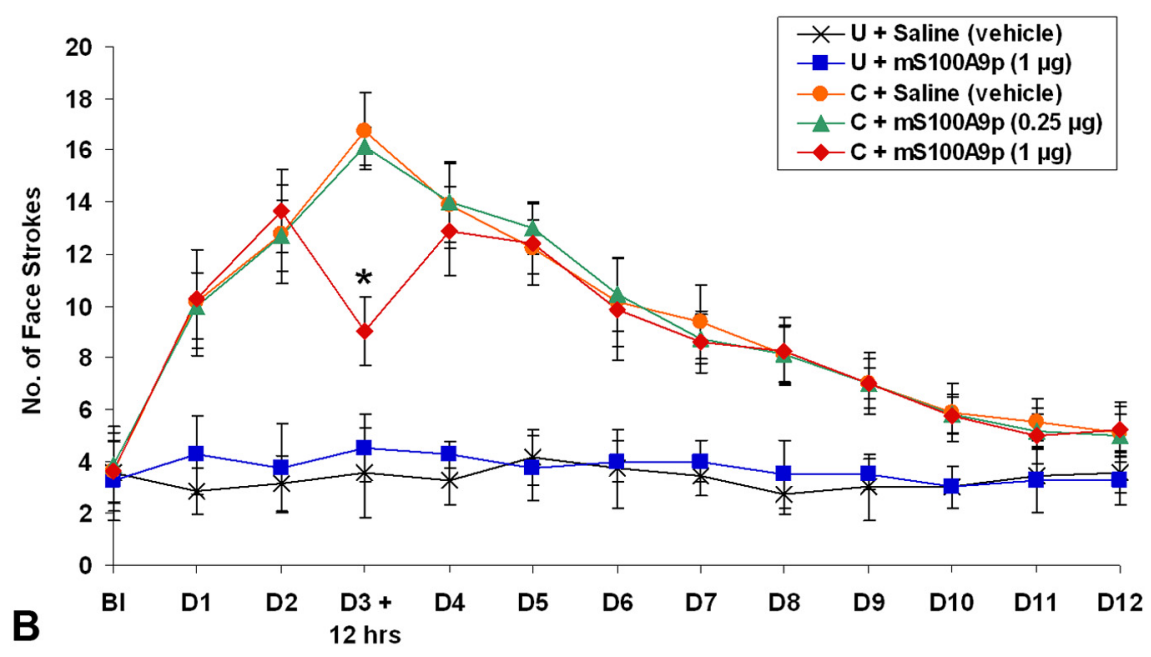

Effect of mS100A9p on Behavioral Responses - Barrel Somatosensory Cortex

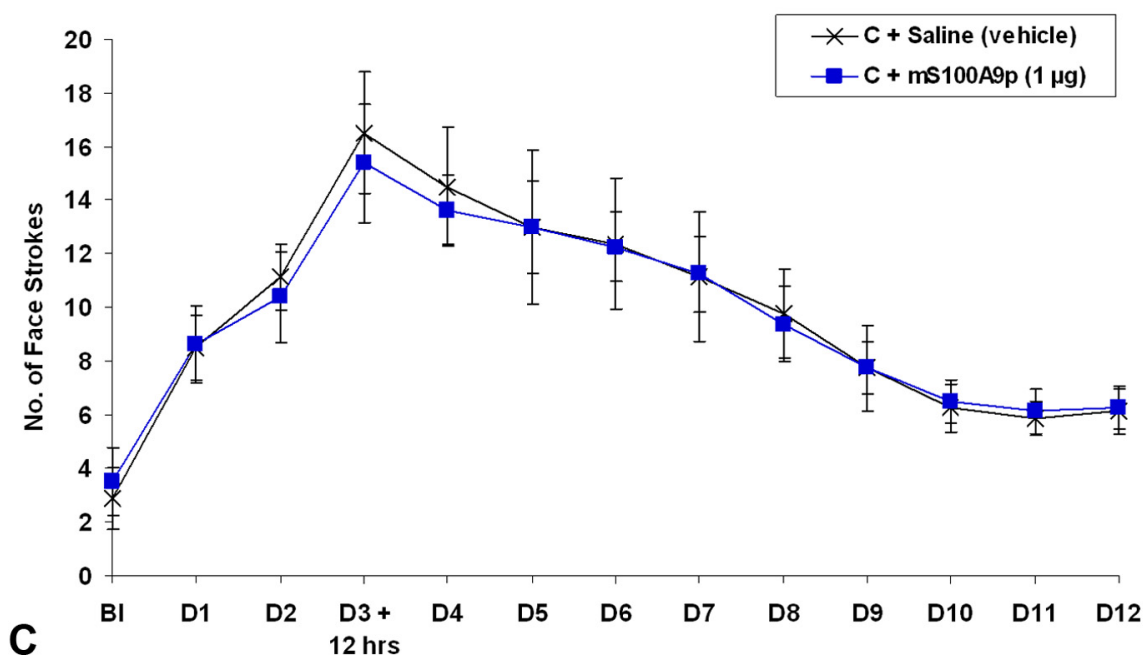

Figure 7. Responses to von Frey hair stimulation of the face after facial carrageenan injection, followed by bilateral injection of mS100A9p into the lateral ventricles $(\boldsymbol{A})$, dorsolateral PFCTX (B), or somatosensory cortex (C). The $y$-axis represents number of responses to von Frey hair stimulation of the carrageenan-injected areas of the face. Mice that received facial carrageenan injection plus intracerebroventricular injection of $2 \mu \mathrm{g}$ of mS100A9p (per side) in the lateral ventricles or intracortical injection of $1 \mu \mathrm{g}$ of mS100A9p (per side) in the dorsolateral PFCTX showed significantly reduced nociceptive responses $12 \mathrm{~h}$ after injection compared with facial carrageenan plus intracerebroventricular or intracortical saline-injected mice $(p<0.05)$. In contrast, intracortical recruitment of lymphocytes, monocytes, and neutrophils during inflammation (Johnston et al., 1996; Johnston and Kubes, 1999). ICAM-1 is expressed on endothelial cells and is important in transendothelial migration of leukocytes (Antonelli et al., 2001; Frank and Lisanti, 2008). JAM2 is expressed in venules and plays an important role in tight junction assembly in epithelial and endothelial cells (Liu et al., 2000; Johnson-Leger et al., 2002). CLDN5 is a transmembrane protein present in tight junctions of endothelial cells and is a component of the blood-brain barrier (Nitta et al., 2003; Amasheh et al., 2005). Increased expression of the adhesion molecules may enhance transmigration of leukocytes in the PFCTX during inflammatory pain.

There was no significant difference in gene expression between non-perfused and perfused PFCTXs $3 \mathrm{~d}$ after facial carrageenan injection. In contrast, a previous study demonstrated significantly lower spinal levels of S100a8 and S100a9 transcripts in perfused compared with nonperfused animals $24 \mathrm{~h}$ after hindpaw inflammation (Mitchell et al., 2008). It is possible that leukocytes are more strongly adherent to the endothelium at $3 \mathrm{~d}$ postcarrageenan injection. Moreover, immunohistochemical analyses demonstrated that $\sim 70 \%$ of S100A9-expressing cells were localized in capillaries adherent to vWF-positive endothelial cells, and 30\% were found in the brain parenchyma in both perfused and non-perfused PFCTXs after facial carrageenan injection.

Analyses of the blood of facial carrageenan-injected mice showed increased expression of several genes that were upregulated in the PFCTX, i.e., S100a8, S100a9, Lcn2, Fcgr1, Cd52, and Mpo. This suggests preactivation of leukocytes at the site of carrageenan-induced inflammation and transmigration of activated circulating leukocytes into the brain. In contrast, other immune-related genes, Il2rg, Fcgr2b, C1qb, Ptprc, and Ccl12 were upregulated in the PFCTX, but not blood. These may be induced in neural cells as a result of increased neuronal activity during pain or as a result of entry of leukocytes into the brain and interaction with neural tissues.

$\leftarrow$

injection of $1 \mu \mathrm{g}$ of mS100A9p (per side) into the somatosensory cortex was ineffective in producing antinociception. $\mathrm{U}$, Untreated mice; $C$, carrageenan-injected mice; BI, before injection; 1D to 12D, 1-12 d after injection. Analyzed by oneway ANOVA with Bonferroni's multiple comparison post hoc test. ${ }^{*} p<0.05$. 
Additional work is necessary to elucidate the nature of these potential interactions. A peptide, identical to the $\mathrm{C}$ terminus of murine S100A9 protein (mS100A9p), was synthesized and bilaterally injected into the lateral ventricles or the dorsolateral prefrontal cortices at peak nociceptive response. Mice that received mS100A9p injection in the lateral ventricles or PFCTX showed significantly reduced responses, whereas no significant difference was found after injection into the somatosensory barrel cortex compared with controls. The results suggest that the effect of mS100A9p was attributable to its action at the PFCTX. The findings are consistent with a previous study that showed antinociceptive effect of intraperitoneally administered S100A9 in a mouse model of acute inflammatory peritonitis (Giorgi et al., 1998). Interestingly, spontaneous neuropathic pain attributable to chronic constriction injury in rats was also reduced after treatment with mS100A9p by intraplantar, oral, or intrathecal routes (Paccola et al., 2008). One explanation is that mS100A9p interferes with primary afferent nociceptive signaling by inhibiting N-type voltage-dependent calcium channels (Dale et al., 2009). Another possibility is that S100A8-, S100A9-, and LCN2associated neutrophil infiltration in the PFCTX could lead to immune activation and increased neuronal activity of the PFCTX, resulting in descending control of pain and antinociception.

Our previous microarray study on the brainstem after facial carrageenan injection has shown 22 genes with more than twofold change (Poh et al., 2009). Five genes were identified in common between the brainstem and PFCTX, Lcn2, Vwf, Icam-1, Ccl12, and suppressor of cytokine signaling 3 (Socs-3). Although both the brainstem and PFCTX showed upregulation of immune response and proinflammatory genes, it is possible that defense/ immune cell and endothelial activation in the brainstem after facial carrageenan injection could be pronociceptive (Poh et al., 2009), whereas activation of immune cells in the PFCTX may have an antinociceptive effect. Moreover, certain genes, such as S100a8 and S100a9, were upregulated in the PFCTX but not brainstem. Site-specific changes in different regions of the CNS may be potential targets for control of pain.

Microarray results suggest side differences between left and right PFCTXs that are induced by pain. The difference of 467 altered genes in the left PFCTX in contrast to the 194 genes in the right PFCTX could point to a functional laterality of the PFCTX. However, additional study is necessary to ascertain this finding.

In conclusion, this study demonstrates activation of immune-related genes in the PFCTX during inflammatory pain. It highlights an exciting role of neutrophils in linking peripheral inflammation with immune activation of the PFCTX and antinociception.

\section{References}

Amasheh S, Schmidt T, Mahn M, Florian P, Mankertz J, Tavalali S, Gitter AH, Schulzke JD, Fromm M (2005) Contribution of claudin-5 to barrier properties in tight junctions of epithelial cells. Cell Tissue Res 321:89-96.

Andoh T, Kuraishi Y (2004) Direct action of immunoglobulin G on primary sensory neurons through Fc gamma receptor I. FASEB J 18:182-184.

Antonelli A, Bianchi M, Crinelli R, Gentilini L, Magnani M (2001) Modulation of ICAM-1 expression in ECV304 cells by macrophage-released cytokines. Blood Cells Mol Dis 27:978-991.

Baron R, Baron Y, Disbrow E, Roberts TP (1999) Brain processing of capsaicin-induced secondary hyperalgesia: a functional MRI study. Neurology 53:548-557.

Basbaum AI, Fields HL (1984) Endogenous pain control systems: brainstem spinal pathways and endorphin circuitry. Annu Rev Neurosci 7:309-338.

Benedetti F, Mayberg HS, Wager TD, Stohler CS, Zubieta JK (2005) Neurobiological mechanisms of the placebo effect. J Neurosci 25:10390-10402.

Blank MC, Stefanescu RN, Masuda E, Marti F, King PD, Redecha PB, Wurzburger RJ, Peterson MG, Tanaka S, Pricop L (2005) Decreased tran- scription of the human FCGR2B gene mediated by the $-343 \mathrm{G} / \mathrm{C}$ promoter polymorphism and association with systemic lupus erythematosus. Hum Genet 117:220-227.

Brooks J, Tracey I (2005) From nociception to pain perception: imaging the spinal and supraspinal pathways. J Anat 207:19-33.

Bundgaard JR, Sengeløv H, Borregaard N, Kjeldsen L (1994) Molecular cloning and expression of a cDNA encoding NGAL: a lipocalin expressed in human neutrophils. Biochem Biophys Res Commun 202:1468-1475.

Coull JA, Beggs S, Boudreau D, Boivin D, Tsuda M, Inoue K, Gravel C, Salter MW, De Koninck Y (2005) BDNF from microglia causes the shift in neuronal anion gradient underlying neuropathic pain. Nature 438:1017-1021.

Cui M, Feng Y, McAdoo DJ, Willis WD (1999) Periaqueductal gray stimulation-induced inhibition of nociceptive dorsal horn neurons in rats is associated with the release of norepinephrine, serotonin, and amino acids. J Pharmacol Exp Ther 289:868 -876.

Dale CS, Altier C, Cenac N, Giorgi R, Juliano MA, Juliano L, Zamponi GW, Vergnolle N (2009) Analgesic properties of S100A9 C-terminal domain: a mechanism dependent on calcium channel inhibition. Fundam Clin Pharmacol 23:427-438.

DeLeo JA, Tanga FY, Tawfik VL (2004) Neuroimmune activation and neuroinflammation in chronic pain and opioid tolerance/hyperalgesia. Neuroscientist 10:40-52.

Dennis G Jr, Sherman BT, Hosack DA, Yang J, Gao W, Lane HC, Lempicki RA (2003) DAVID: database for annotation, visualization, and integrated discovery. Genome Biol 4:P3.

Flo TH, Smith KD, Sato S, Rodriguez DJ, Holmes MA, Strong RK, Akira S, Aderem A (2004) Lipocalin 2 mediates an innate immune response to bacterial infection by sequestrating iron. Nature 432:917-921.

Forsyth KD, Chua KY, Talbot V, Thomas WR (1993) Expression of the leukocyte common antigen $\mathrm{CD} 45$ by endothelium. J Immunol 150:3471-3477.

Frank PG, Lisanti MP (2008) ICAM-1: role in inflammation and in the regulation of vascular permeability. Am J Physiol Heart Circ Physiol 295:H926-H927.

Gebhardt C, Németh J, Angel P, Hess J (2006) S100A8 and S100A9 in inflammation and cancer. Biochem Pharmacol 72:1622-1631.

Giorgi R, Pagano RL, Dias MA, Aguiar-Passeti T, Sorg C, Mariano M (1998) Antinociceptive effect of the calcium-binding protein MRP-14 and the role played by neutrophils on the control of inflammatory pain. J Leukoc Biol 64:214-220.

Grimbaldeston MA, Geczy CL, Tedla N, Finlay-Jones JJ, Hart PH (2003) S100A8 induction in keratinocytes by ultraviolet A irradiation is dependent on reactive oxygen intermediates. J Invest Dermatol 121:1168-1174.

Habib T, Senadheera S, Weinberg K, Kaushansky K (2002) The common gamma chain (gamma c) is a required signaling component of the IL-21 receptor and supports IL-21-induced cell proliferation via JAK3. Biochemistry 41:8725-8731.

Handwerker HO, Forster C, Kirchhoff C (1991) Discharge patterns of human C-fibers induced by itching and burning stimuli. J Neurophysiol 66:307-315

Hua S, Cabot PJ (2010) Mechanisms of peripheral immune-cell-mediated analgesia in inflammation: clinical and therapeutic implications. Trends Pharmacol Sci 31:427-433.

Huang da W, Sherman BT, Lempicki RA (2009) Systematic and integrative analysis of large gene lists using DAVID bioinformatics resources. Nat Protoc 4:44-57.

Ingvar M (1999) Pain and functional imaging. Philos Trans R Soc Lond B Biol Sci 354:1347-1358.

Johansson F, Kramer F, Barnhart S, Kanter JE, Vaisar T, Merrill RD, Geng L, Oka K, Chan L, Chait A, Heinecke JW, Bornfeldt KE (2008) Type 1 diabetes promotes disruption of advanced atherosclerotic lesions in LDL receptor-deficient mice. Proc Natl Acad Sci U S A 105:2082-2087.

Johnson-Léger CA, Aurrand-Lions M, Beltraminelli N, Fasel N, Imhof BA (2002) Junctional adhesion molecule-2 (JAM-2) promotes lymphocyte transendothelial migration. Blood 100:2479-2486.

Johnston B, Kubes P (1999) The alpha4-integrin: an alternative pathway for neutrophil recruitment? Immunol Today 20:545-550.

Johnston B, Issekutz TB, Kubes P (1996) The alpha 4-integrin supports leukocyte rolling and adhesion in chronically inflamed postcapillary venules in vivo. J Exp Med 183:1995-2006.

Kakinoki Y, Kubota H, Yamamoto Y (2004) CD64 surface expression on neutrophils and monocytes is significantly up-regulated after stimulation 
with granulocyte colony-stimulating factor during $\mathrm{CHOP}$ chemotherapy for patients with non-Hodgkin's lymphoma. Int J Hematol 79:55-62.

Kerkhoff C, Klempt M, Kaever V, Sorg C (1999) The two calcium-binding proteins, S100A8 and S100A9, are involved in the metabolism of arachidonic acid in human neutrophils. J Biol Chem 274:32672-32679.

Kerkhoff C, Sorg C, Tandon NN, Nacken W (2001) Interaction of S100A8/ S100A9-arachidonic acid complexes with the scavenger receptor CD36 may facilitate fatty acid uptake by endothelial cells. Biochemistry 40:241-248.

Liebeskind JC, Guilbaud G, Besson JM, Oliveras JL (1973) Analgesia from electrical stimulation of the periaqueductal gray matter in the cat: behavioral observations and inhibitory effects on spinal cord interneurons. Brain Res 50:441-446.

Liu Y, Nusrat A, Schnell FJ, Reaves TA, Walsh S, Pochet M, Parkos CA (2000) Human junction adhesion molecule regulates tight junction resealing in epithelia. J Cell Sci 113:2363-2374.

Livak KJ, Schmittgen TD (2001) Analysis of relative gene expression data using real-time quantitative PCR and $2^{-\Delta \Delta C T}$ method. Methods 25:402-408.

Maihöfner C, Handwerker HO (2005) Differential coding of hyperalgesia in the human brain: a functional MRI study. Neuroimage 28:996-1006.

Maihöfner C, Schmelz M, Forster C, Neundörfer B, Handwerker HO (2004) Neural activation during experimental allodynia: a functional magnetic resonance imaging study. Eur J Neurosci 19:3211-3218.

Mayer DJ, Price DD (1976) Central nervous system mechanisms of analgesia. Pain 2:379-404.

Mitchell K, Yang HY, Tessier PA, Muhly WT, Swaim WD, Szalayova I, Keller JM, Mezey E, Iadarola MJ (2008) Localization of S100A8 and S100A9 expressing neutrophils to spinal cord during peripheral tissue inflammation. Pain 134:216-231.

Newton RA, Hogg N (1998) The human S100 protein MRP-14 is a novel activator of the beta 2 integrin Mac-1 on neutrophils. J Immunol 160:1427-1435.

$\mathrm{Ng} \mathrm{CH}$, Ong WY (2001) Increased expression of gamma-aminobutyric acid transporters GAT-1 and GAT-3 in the spinal trigeminal nucleus after facial carrageenan injections. Pain 92:29-40.

Nitta T, Hata M, Gotoh S, Seo Y, Sasaki H, Hashimoto N, Furuse M, Tsukita S (2003) Size-selective loosening of the blood-brain barrier in claudin5-deficient mice. J Cell Biol 161:653-660.

Paccola CC, Gutierrez VP, Longo I, Juliano L, Juliano MA, Giorgi R (2008) Antinociceptive effect of the C-terminus of murine S100A9 protein on experimental neuropathic pain. Peptides 29:1806-1814.

Paxinos G, Franklin KBJ (2004) The mouse brain in stereotaxic coordinates, Compact Ed 2. Amsterdam: Elsevier Academic.

Petrovic P, Kalso E, Petersson KM, Ingvar M (2002) Placebo and opioid analgesia: imaging a shared neuronal network. Science 295:1737-1740.

Peyron R, Laurent B, García-Larrea L (2000) Functional imaging of brain responses to pain. A review and meta-analysis (2000). Neurophysiol Clin 30:263-288.

Poh KW, Lutfun N, Manikandan J, Ong WY, Yeo JF (2009) Global gene expression analysis in the mouse brainstem after hyperalgesia induced by facial carrageenan injection-evidence for a form of neurovascular coupling? Pain 142:133-141.

Raftery MJ, Harrison CA, Alewood P, Jones A, Geczy CL (1996) Isolation of the murine S100 protein MRP14 (14 kDa migration-inhibitory-factorrelated protein) from activated spleen cells: characterization of posttranslational modifications and zinc binding. Biochem J 316:285-293.

Rahman ZS, Niu H, Perry D, Wakeland E, Manser T, Morel L (2007) Expression of the autoimmune Fcgr2b NZW allele fails to be upregulated in germinal center B cells and is associated with increased IgG production. Genes Immun 8:604-612.

Ramos JM (2007) Placebo effect and pain: brain bases (in Spanish). Neurologia 22:99-105.

Ratthé C, Pelletier M, Chiasson S, Girard D (2007) Molecular mechanisms involved in interleukin-4-induced human neutrophils: expression and regulation of suppressor of cytokine signaling. J Leukocyte Biol 81:1287-1296.

Ren K, Dubner R (2008) Neuron-glia crosstalk gets serious: role in pain hypersensitivity. Curr Opin Anaesthesiol 21:570-579.

Ren K, Dubner R (2010) Interactions between the immune and nervous systems in pain. Nat Med 16:1267-1276.

Rittner HL, Brack A, Stein C (2008) Pain and the immune system. Br J Anaesth 101:40-44.
Rodig SJ, Abramson JS, Pinkus GS, Treon SP, Dorfman DM, Dong HY, Shipp MA, Kutok JL (2006) Heterogeneous CD52 expression among hematologic neoplasms: implications for the use of alemtuzumab (CAMPATH1H). Clin Cancer Res 12:7174-7179.

Sarafi MN, Garcia-Zepeda EA, MacLean JA, Charo IF, Luster AD (1997) Murine monocyte chemoattractant protein (MCP)-5: a novel CC chemokine that is a structural and functional homologue of human MCP-1. J Exp Med 185:99-109.

Scholz J, Woolf CJ (2007) The neuropathic pain triad: neurons, immune cells and glia. Nat Neurosci 10:1361-1368.

Sontheimer RD, Racila E, Racila DM (2005) Clq: its functions within the innate and adaptive immune responses and its role in lupus autoimmunity. J Invest Dermatol 125:14-23.

Soyfoo MS, Roth J, Vogl T, Pochet R, Decaux G (2009) Phagocyte-specific S100A8/A9 protein levels during disease exacerbations and infections in systemic lupus erythematosus. J Rheumatol 36:2190-2194.

Spielman L, Winger D, Ho L, Aisen PS, Shohami E, Pasinetti GM (2002) Induction of the complement component $\mathrm{ClqB}$ in brain of transgenic mice with neuronal overexpression of human cyclooxygenase-2. Acta Neuropathol 103:157-162.

Sunahori K, Yamamura M, Yamana J, Takasugi K, Kawashima M, Yamamoto H, Chazin WJ, Nakatani Y, Yui S, Makino H (2006) The S100A8/A9 heterodimer amplifies proinflammatory cytokine production by macrophages via activation of nuclear factor kappa B and p38 mitogen-activated protein kinase in rheumatoid arthritis. Arthritis Res Ther 8:R69.

Suomela S, Cao L, Bowcock A, Saarialho-Kere U (2004) Interferon alphainducible protein 27 (IFI27) is upregulated in psoriatic skin and certain epithelial cancers. J Invest Dermatol 122:717-721.

Tanaka SS, Yamaguchi YL, Tsoi B, Lickert H, Tam PP (2005) IFITM/Mil/ fragilis family proteins IFITM1 and IFITM3 play distinct roles in mouse primordial germ cell homing and repulsion. Dev Cell 9:745-756.

Valet M, Sprenger T, Boecker H, Willoch F, Rummeny E, Conrad B, Erhard P, Tolle TR (2004) Distraction modulates connectivity of the cingulo-frontal cortex and the midbrain during pain: an fMRI analysis. Pain 109:399-408.

Verge GM, Milligan ED, Maier SF, Watkins LR, Naeve GS, Foster AC (2004) Fractalkine (CX3CL1) and fractalkine receptor (CX3CR1) distribution in spinal cord and dorsal root ganglia under basal and neuropathic pain conditions. Eur J Neurosci 20:1150-1160.

Viemann D, Strey A, Janning A, Jurk K, Klimmek K, Vogl T, Hirono K, Ichida F, Foell D, Kehrel B, Gerke V, Sorg C, Roth J (2005) Myeloid-related proteins 8 and 14 induce a specific inflammatory response in human microvascular endothelial cells. Blood 105:2955-2962.

Viemann D, Barczyk K, Vogl T, Fischer U, Sunderkötter C, Schulze-Osthoff $\mathrm{K}$, Roth J (2007) MRP8/MRP14 impairs endothelial integrity and induces a caspase-dependent and -independent cell death program. Blood 109:2453-2460.

Vos BP, Strassman AM, Maciewicz RJ (1994) Behavioral evidence of trigeminal neuropathic pain following chronic constriction injury to the rat's infraorbital nerve. J Neurosci 14:2708-2723.

Wager TD (2005) The neural bases of placebo effects in anticipation and pain. Semin Pain Med 3:22-30.

Watkins LR, Maier SF (1999) Implications of immune-to-brain communication for sickness and pain. Proc Natl Acad Sci U S A 96:7710-7713.

Xie YF, Huo FQ, Tang JS (2009) Cerebral cortex modulation of pain. Acta Pharmacol Sin 30:31-41.

Yan QW, Yang Q, Mody N, Graham TE, Hsu CH, Xu Z, Houstis NE, Kahn BB, Rosen ED (2007) The adipokine lipocalin 2 is regulated by obesity and promotes insulin resistance. Diabetes 56:2533-2540.

Yeo JF, Ong WY, Ling SF, Farooqui AA (2004) Intracerebroventricular injection of phospholipases A2 inhibitors modulates allodynia after facial carrageenan injection in mice. Pain 112:148-155.

Zhang YQ, Tang JS, Yuan B, Jia H (1997) Inhibitory effects of electrically evoked activation of ventrolateral orbital cortex on the tail-flick reflex are mediated by periaqueductal gray in rats. Pain 72:127-135.

Zhuang ZY, Kawasaki Y, Tan PH, Wen YR, Huang J, Ji RR (2007) Role of the CX3CR1/p38 MAPK pathway in spinal microglia for the development of neuropathic pain following nerve injury-induced cleavage of fractalkine. Brain Behav Immun 21:642-651.

Zubieta JK, Stohler CS (2009) Neurobiological mechanisms of placebo responses. Ann N Y Acad Sci 1156:198-210. 